\title{
PENYEBAB KEMISKINAN NELAYAN TRADISIONAL DI KOTA PADANG
}

\author{
Nurma Yenni ${ }^{1^{*}}$ \\ 1 Jurusan Matematika, FMIPA, Universitas Negeri Padang, \\ Indonesia \\ *E-mail : nurmayenni59@gmail.com \\ Abstrak. Tulisan ini menjelaskan tentang penyebab \\ kemiskinan di kota Padang. Kemiskinan adalah salah satu \\ masalah dalam perekonomian Indonesia yang kompleks dan \\ mendasar. Perlu dicari solusi untuk mengatasi atau paling \\ tidak mengurangi tingkat kemiskinan. \\ Kata Kunci : Kemiskinan, Nelayan Tradisional
}

1. Pendahuluan

Pertumbuhan ekonomi dan kemiskinan merupakan indikator penting untuk melihat keberhasilan pembangunan suatu negara. Setiap Negara akan berusaha keras untuk mencapai pertumbuhan ekonomi yang optimal dan menurunkan angka kemiskinan. Di banyak negara di dunia syarat utama bagi terciptanya penurunan kemiskinan adalah pertumbuhan ekonomi. Namun, kondisi di negara-negara berkembang termasuk Indonesia pertumbuhan ekonomi yang dicapai ternyata juga diiringi dengan munculnya permasalahan meningkatnya jumlah penduduk yang hidup dibawah garis kemiskinan. Bagi Indonesia, kemiskinan sudah sejak lama menjadi persoalan bangsa, di mana hingga sekarang masih belum menunjukkan tanda-tanda akan berakhir. Berdasarkan hasil Survei Sosial Ekonomi Nasional (Susenas) yang dilakukan BPS, jumlah penduduk Indonesia yang hidup di bawah garis kemiskinan tahun 2009 tercatat masih 
cukup besar yakni, sekitar 32,5 juta jiwa atau lebih kurang 14,2 persen.

Menurut Kusnadi,2008:27 menyatakan secara geografis masyarakat nelayan adalah masyarakat yang hidup, tumbuh, dan berkembang di kawasan pesisir, yakni suatu kawasan transisi antara wilayah darat dan laut. Sebagai suatu sistem, masyarakat nelayan terdiri atas kategori-ketegori sosial yang membentuk kesatuan sosial. Mereka juga memiliki sistem nilai dan symbolsimbol kebudayaan sebagai referensi perilaku mereka sehari-hari . Pekerjaan sebagai nelayan tradisional lebih banyak mengandalkan kekuatan otot, atau tenaga, sehingga para nelayan tradisional ini mengesampingkan tingkat pendidikan mereka. Namun masalah lain akan muncul ketika para nelayan tradisional ini ingin beralih profesi yang hasilnya menjanjikan untuk memenuhi kebutuhan sehari-hari mereka. Dengan latar belakang tingkat pendidikan mereka yag rendah maka hal tersebut akan menyusahkan mereka untuk mendapatkan pekerjaan yang layak.

Tingkat pendidikan sebagai salah satu indikator dari Kualitas Sumber Daya Manusia, indikator ini sangat menentukan seseorang atau sekelompok orang berstatus golongan masyarakat miskin atau bukan miskin. Dimana mereka yang berpendidikan rendah, produktivitasnya rendah. Rendahnya produktifitas akan berpengaruh pada rendahnya pendapatan. Sedangkan rendahnya tingkat pendapatan merupakan salah satu ciri dari penduduk miskin.

Faktor-faktor yang bersifat kompleks menyebabkan kemiskinan di kalangan nelayan. Lebih spesifik lagi, Kusnadi (2002:19) menyatakan bahwa kemiskinan yang diderita oleh masyarakat nelayan bersumber dari faktor-faktor sebagai berikut:"(1) faktor alamiah, yakni berkaitan dengan fluktasi musim -musim penangkapan dan struktur alamiah sumberdaya ekonomi 
dan; (2) faktor non-alamiah, yakn berhubungan dengan keterbatasan daya jangkau teknologi penangkapan, ketimpangan dalam sistem bagi hasil dan tidak adanya jaminan sosial tenaga kerja yang pasti, lemahnya penguasaan jaringan pemasaran dan belum berfungsinya lembaga koperasi nelayan yang ada serta dampak negatif kebijakan modernisasi perikanan yang telah berlangsung sejak seperempat abad terakhir". Dengan kata lain dapat diakatakan bahwa faktor kemiskinan di kalangan nelayan dapat sebabkan oleh faktor internal meliputi keterbatasan dibidang pendidikan, kurangnya kesempatan akses teknologi modern dan tidak memiliki modal yang cukup. Faktor lainnya adalah faktor eksternal yaitu terbatasnya potensi sumber daya laut yang bisa dimanfaatkan nelayan, persaingan yang intensif, mekanisme pasar, posisi tawar nelayan yang dihadapi tengkulak, keadaan infrastruktur pelabuhan perikanan, dan yuridiksi otonomi adalah beban yang mempersulit keadaan kemiskinan nelayan tradisional.

Tabel 1. Jumlah Nelayan di Kawasan Pantai Kota Padang

\begin{tabular}{lll} 
No & Kecamatan & Nelayan \\
\hline 1 & Bungus Teluk Kabung & 286 \\
\hline 2 & Padang Selatan & 139 \\
\hline 3 & Padang Barat & 142 \\
\hline 4 & Padang Utara & \multicolumn{1}{l}{133} \\
\hline 5 & Koto Tangah & 323 \\
\hline Jumlah & & 1.023
\end{tabular}

Sumber: Padang dalam angka 2014

Berdasarkan data di atas, dapat diketahui bahwa jumlah nelayan di Kota Padang adalah sebanyak 1.023 jiwa dari jumlah penduduk kota Padang tahun 2014 adalah 876.678 jiwa. 
2. Metode Penelitian

Metode penelitian dalam penelitian ini adalah metode deskriptif kualitatif dengan menggunakan data primer dan sekunder dalam mengidentifikasi permasalahan internal nelayan tradisional Kota Padang berdasarkan faktor-faktor sosial budaya penyebab kemiskinan. Menurut Nawawi (1993:87) menyatakan bahwa diskriptif kualitatif merupakan salah satu teknik penggambaran atau lukisan keadaan subyek atau obyek penelitian berdasarkan fakta-fakta yang tampak sebagai mana adanya. Diskripsi menganai data bertujuan mengemukakan gejala-gejala secara lengkap agar permasalahan lebih tampak jelas.

3. Hasil dan Pembahasan

- Kualitas Sumber Daya Manusia

Bagi nelayan pekerjaan melaut tidak memerlukan latar belakang pendidikan yang tinggi, mereka beranggapan sebagai seorang nelayan tradisional sedikit banyak merupakan pekerjaan kasar yang lebih banyak mengandalkan otot dan pengalaman bukan pemikiran, maka setinggi apapun tingkat pendidikan nelayan itu tidaklah akan mempengaruhi kemampuan melaut mereka.

- Kebiasaan Nelayan

Nelayan adalah suatu pekerjaan yang bergantung pada kemurahan alam, ketika alam memberikan sumberdaya nya sudah sepatutnya kita harus bersyukur dan menjaganya untuk keperluan berikutnya. Tingkat eksploitasi nelayan terhadap laut sangatlah besar.

- Faktor Kualitas Sumber Daya Manusia

Rendahnya tingkat pendidikan nelayan tradisional di Pulau Buluh yakni hanya 10,7 persen responden yang lulus Sekolah Menengah Atas (SMA), kemudian 14,6 persen responden lulusan Sekolah 
Menengah Pertama, dan yang paling banyak 56,3 responden yang hanya lulus Sekolah Dasar (SD), serta tingkat pendidikan yang paling rendah yakni responden sebanyak 8,4 persen tidak lulus sekolah dasar. Hal ini sesuai dengan penelitian yang dilakukan Sudarso (2008) yang menyatakan nelayan khususnya nelayan tradisional, pada umumnya mereka mempunyai ciri yang sama yaitu kurangnya pendidikan. Kemudian BKKBN juga menyebutkan bahwa masyarakat miskin dapat dilihat dari tingkat pendidikan kepala keluarga yakni tidak sekolah atau tidak tamat Sekolah Dasar (SD) atau Tamat Sekolah Dasar (SD).

- Faktor Teknologi yang Digunakan

Nelayan tradisional di kota Padang sangat bersaing dengan nelayan yang menggunakan perahu motor untuk mencari ikan. Nelayan yang menggunakan motor biasanya dikategorikan menjadi nelayan modern, modernitas saat ini mengalami pergeseran, modernitas tidak hanya menggunakan perahu motor, melainkan pada besar atau kecilnya motor perahu yang digunakan serta tingkat kemampuan penangkapan ikan dalam mengekploitasi ikan sendiri.

Nelayan Tradisional Desa Kedungringin pada umumnya masih memakai teknologi penangkapan ikan yang sangat sederhana, adapun peralatan yang di pakai meliputi : a. perahu, perahu yang digunakan pada umumnya berbahan kayu yang berukuran panjang 4-5 meter dan lebar 0,5-1 meter. Dengan tenaga penggeraknya memakai layar atau mesin tempel, b. jaring, jaring digunakan untuk proses penangkapan ikan dilaut, jaring yang dipakai mereka sebut dengan jaring slodo. Dan jangkauan penangkapan ikanya pun terbatas.

- Peran Lembaga Ekonomi

Lembaga Ekonomi adalah faktor yang berpengaruh dan bisa 
menjadi salah satu kendala utama bila pasar tidak berkembang. Untuk mengembangkan pasar bagi produk- produk yang dihasilkan nelayan tradisional Kota Padang maka upaya yang dilakukan adalah mendekatkan masyarakat dengan pasar seperti eksportir hasil perikanan dan pengepul. Keuntungan dari hubungan seperti ini yaitu nelayan mendapat jaminan pasar dan harga, serta pembinaan terhadap nelayan tradisional terutama dalam hal kualitas barang bisa dilaksanakan, serta nelayan juga dapat mendapat bantuan modal bagi pengembangan usaha yang dihasilkan.

- Pekerjaan alternatif

Penghasilan seorang nelayan tradisonal tidak bisa diandalkan untuk memenuhi kebutuhan sehari-hari yang tiap hari semakin melambung. Jika nelayan tradisional di Kota Padang hanya mengandalkan pendapatanya dari hasil melaut maka kehidupan mereka tidak akan berubah, oleh karena itu untuk menunjang penghasilanya perlu kiranya pekerjaan alternatif untuk menambah pendapatan serta untuk pemenuhan kebutuhan hidup sehari-hari mereka.

4. Kesimpulan

Hasil penelitian yang telah dilakukan terhadap Faktor-faktor kemiskinan nelayan tradisional di Kota Padang maka dapat diambil kesimpulan sebagai berikut:

1. Kualitas Sumber Daya Manusia, yang di tandai dengan Tingkat pendidikan yang rendah sebagai salah satu indikator dari rendahnya Kualitas Sumber Daya Manusia, indikator ini sangat menentukan seseorang atau sekelompok orang berstatus golongan masyarakat miskin atau bukan miskin. Dimana mereka yang berpendidikan rendah, produktivitasnya rendah. Rendahnya produktifitas akan berpengaruh pada rendahnya pendapatan. 
Sedangkan rendahnya tingkat pendapatan merupakan salah satu ciri dari penduduk miskin.

2. Pekerjaan Alternatif menjadi penting bagi nelayan tradisional Kota Padang ketika laut tidak lagi menyediakan ikan untuk ditangkap, karena pada kenyataanya pekerjaan sebagai nelayan adalah pekerjaan yang bergantung kepada kemurahan alam (laut) dalam menyediakan sumber dayanya. Apalagi penghasilan nelayan tradisional dari kegiatan melaut tidak bisa diandalkan, bahkan untuk memenuhi berbagai kebutuhan sehari-hari tidak jarang harus meminjam kepada saudara.

3. Kebiasaan nelayan, hal tersebut ditandai dengan kebiasaan atau sosial budaya yang kurang memperhatikan, dimana mereka mempunyai pola hidup yang kurang memperhitungkan kebutuhan masa depanya, artinya setiap kali mendapat hasil tangkapan yang melimpah atau lebih maka pada saat itu pula mereka akan membelanjakan atau menghabiskannya. Misalnya mereka membeli perhiasan, pakaian, dan sebagainya secara berlebihan.

4. Teknologi yang digunakan, hal tersebut ditandai dengan masih tradisionalnya peralatan yang digunakan yakni badan perahu berbahan kayu, ada yang menggunakan motor tempel, juga ada yang menggunakan layar sebagai pengganti motor tempel, panjang antara 5-8 meter, lebar 0,5-1 meter, awak perahu 1-5 orang, kecepatan jelajah terbatas,

5. Peranan lembaga ekonomi, hal tersebut disinyalir karna belum adanya lembaga ekonomi atau lembaga perkumpulan nelayan yang bertugas menaungi keperluan, menyalurkan hasil tangkapan, serta memfasilitasi kebutuhan-kebutuhan nelayan tradisional.

Referensi : 
Darwis, dkk. (2013). KAJIAN KEMISKINAN RUMAH TANGGA NELAYAN TRADISIONAL DI PULAU BULUH KELURAHAN PULAU BULUH KECAMATAN BULANG KOTA BATAM PROVINSI KEPULAUAN RIAU.

Hamdani, H dan Kusuma, W. (2013). FAKTOR PENYEBAB KEMISKINAN NELAYAN TRADISIONAL.

Hidayat, M. (2018). PROBLEMATIKA INTERNAL NELAYAN TRADISIONAL KOTA PADANG: STUDI FAKTOR-FAKTOR SOSIAL BUDAYA PENYEBAB KEMISKINAN. SOCIUS, 4(1), 31-40. doi:10.24036/scs.v4i1.15https://doi.org/10.24036/scs.v4i1.15. 